\title{
Проблема формування готовності до сімейного життя та відповідального батьківства у молоді
}

\begin{abstract}
Анотація. У статті розглядаються проблеми формування у сучасної молоді уявлення про створення власної родини та готовності до відповідального батьківства. Процеси становлення молодих сімей зараз у більшості випадків проходить у складних і суперечливих умовах, які характеризуються зміною суспільних відносин та появою нових иінностей. Розглянуто шляхи вирімення иієї проблеми, запропоновано заходи щодо ї̈ попередження через особливості підготовки молодого покоління до створення сім'ї.

Ключові слова: особистість, готовність молоді до сімейного життя, відповідальне батьківство, становлення молодої сім'ї, подружжя, суспільство, молодь, сімейна адаптаиія, проблеми сім'ї, иінності.
\end{abstract}

Постановка проблеми. У сучасній Україні питання підготовки до подружжя та сімейного життя $є$ вкрай актуальним. Люди стають членами такого соціального інституту як сім'я з моменту народження. Від того, в якій сім'ї вони народилися, залежить багато чого в їхньому житті, в першу чергу, якість засвоєння статево-рольових взаємин і первинні навички їх побудови. Підготовка до майбутньої сімейного життя завжди була одним з головних завдань, не менш важливим, ніж підготовка до праці. $€$ сім'ї, які на власному прикладі, відповідним вихованням здатні прищепити своїм дітям сімейні цінності, сформувати в них відповідальне ставлення до шлюбу та батьківства. Проте глобальні трансформаційні процеси, що відбуваються фактично в усьому суспільстві, обумовлюють необхідність розроблення і запровадження спеціальних програм та заходів, які спрямовані на підготовку молоді до створення сім’ї та відповідального батьківства.

Аналіз останніх досліджень і публікацій. Експерти вважають, що з початку 1990-х років українське суспільство 3 різних причин (інфляція, соціальна та політична нестабільність, відсутність правових гарантій, невизначеність майбутнього) вступило в період дезадаптації та переоцінки цінностей. Відомий соціолог Є.І. Головаха назвав цей феномен «аномічна деморалізованість» людей, які опинилися в умовах стрімкого змінення звичних норм та цінностей [3]. Тобто, за цей час ціле покоління молоді встигло пристосуватися до швидкозмінних умов життя і успішно оминати вічні загальноприйняті суспільні цінності, при цьому юнаки та дівчата виправдовують таку стратегію «вимогами часу». Торкнулись процеси знецінення i сімейних стосунків та батьківства. Так, у демографічних та соціологічних дослідженнях розглядаються проблеми сім'ї, їх причини, закономірності розвитку; ціннісні орієнтації майбутніх батьків (О. Баланірєва, О. Яременко, В. Бойко, Ю. Якубова, В. Береговий та ін.). У соціально-психологічній літературі достатньо глибоко розкриті проблеми пов'язані з психологічною готовністю чоловіка та жінки стати батьками, вплив психологічної атмосфери сім'ї на психологічний розвиток плоду, на формування позитивного ставлення матері до майбутньої дитини (А. Буттєва, А. Брусиловський, Р. Овчарова, Г. Філіпова та ін.). Аналізуючи науково-практичну літературу, яка присвячена висвітленню соціальнопедагогічної діяльності щодо формування у молоді усвідомленого батьківства, можна констатувати, що комплексна соціальна робота $з$ формування усвідомленого батьківства молоді в Україні на сьогодні майже відсутня. Формування усвідомленого батьківства молоді здійснюється частіше за все в рамках окремих іï складових. Українські дослідники В. Кравець О. Кікінеджі, О. Кізь, які вивчали структуру формування 
усвідомленого батьківства у молоді, виділили такі складові даного процесу, як: демографічне виховання молоді (спрямоване на формування правильної репродуктивної установки), формування контрацептивної культури, підготовка до прокреативної діяльності (інтимні стосунки як засіб відтворення потомства, дітонародження), психолого-педагогічна підготовка майбутніх батьків. Через вищевказані факти підготовка до сімейного життя та відповідального батьківства зараз повинна стати завданням номер один як на рівні держави (освітні установи від загальноосвітніх шкіл до ВНЗ), так і на рівні релігійних установ (церкви, будинки молитви).

Мета статті: розглянути проблему підготовки молоді до сімейного життя та відповідального батьківства, знайти оптимальні шляхи практичної реалізації програм формування готовності до подружніх стосунків.

Результати теоретичного дослідження. Задля реалізації мети дослідження нами було проведено експериментальне дослідження, яке проходило на базі Шосткинської загальноосвітньої школи №8. Механізм експерименту включив в себе три етапи. На першому етапі було проведено анкетування респондентів, 3 метою 3'ясування сутності та критеріїв готовності до сімейного життя 3 позиції юнацтва. На другому етапі здійснювалося формування готовності до сімейного життя в аспекті репродуктивної функції. На третьому етапі експерименту проводилося дослідження готовності до сімейного життя в аспекті репродуктивної функції.

3 метою вивчення рівня готовності до сімейного життя юнацтва нами було проведено анкетування, за результатами якого був здійснений якісний і кількісний аналіз отриманих даних. В анкетуванні взяло участь 25 респондентів. Співвідношення представників обох статей представлено 7 дівчатами (28\%) і 18 юнаками (72\%). 15 респондентів 2000 року народження, 2001 - рік народження, 2 - 1999 року народження. Аналіз отриманих даних показав високу самокритичність, як юнаків, так і дівчат. У 5 балів свою готовність до сімейного життя оцінив лише 1 респондент (4\%). На 4 бали власну готовність оцінили 4 респондента (15\%), задовільною iii визнали 13 осіб (49\%), на 2 бали «готові» 3 людини (12\%), 1 бал в якості оцінки своєї готовності до сімейного життя собі поставили 2 людини (8\%). Цікавим є той факт, що 3 респонденти оцінили власну готовність до сімейного життя в 0 балів (12\%), див. рис. 1.

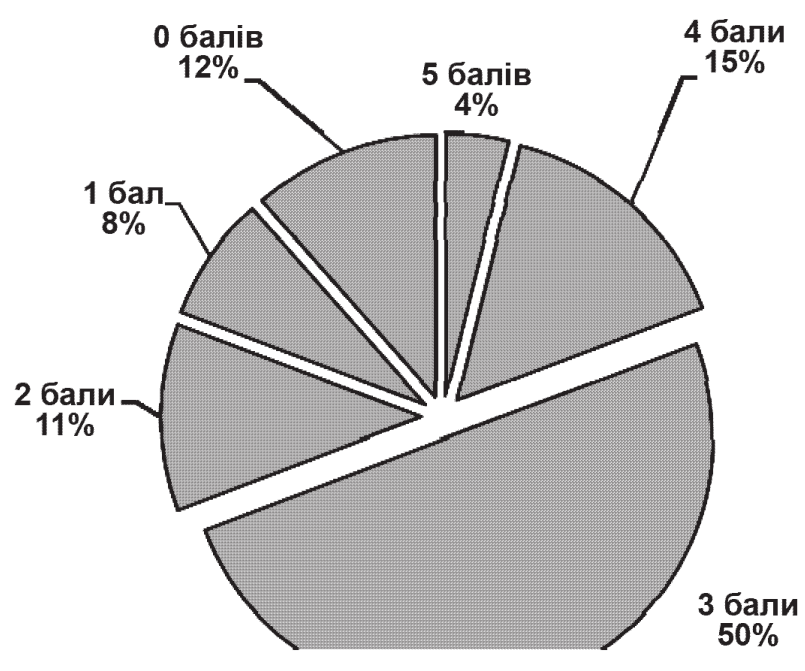

Рис. 1. Оиінка власної готовності до сімейного життя

Особливий інтерес для нас представляли дані про джерело отримання необхідної інформації, яка, на думку респондентів повинна сприяти їх підготовці до сімейного життя. Отримані дані свідчать про те, що школа, на жаль, є слабким інформатором в цьому плані. На епізодичність одержуваної в навчальному закладі інформації вказали 17 осіб (68\%). Практично всі 3 цієї групи респонденти вказали, що це відбувається не часто, іноді випадково або спонтанно. У більшості випадкі в цьому приділяється увага на класних годинах, на факультативах. Решта 8 респондентів (32\%) взагалі не вважають, що школа вирішує це завдання.

Таким чином, ми змушені констатувати, що підготовка до сімейного життя не тільки не досить ефективна в сім'ях, а й практично не ведеться в школі [1]. I якщо перед школою, як перед освітнім закладом, що 
забезпечує отримання середньої освіти, не стоїть спеціальне завдання по роботі в досліджуваному напрямку, то сім'я, порушує функцію виконання цього важливого завдання. Зміна в подібній ситуації, можлива за умови розгляду підготовки до сімейного життя як систематичного, поступового і послідовного процесу. I повинен він розпочинатися задовго до народження дитини. Умовно процес підготовки варто розділити на три етапи: дальший (розпочинається і триває в родині), ближчий (проводиться в освітніх організаціях), безпосередній (безпосередньо перед одруженням наречених і орієнтована на молодь 16-17 років). Здійснюватися підготовка до сімейного життя повинна наступними основними суб'єктами: родиною, освітньовиховними закладами, громадою, релігійними організаціями тощо [7].

Аналіз результатів дослідження. За результатами констатуючого етапу експериментальної частини дослідження можна зробити наступні висновки.

1. Ані сім'я, ані школа не є якісними інформаторомами з даної проблеми (підготовка до сімейного життя). Це обумовлює необхідність ведення цілеспрямованої роботи із підготовки до сімейного життя.

2. Як хлопці, так і дівчата відчувають необхідність бути проінформованими 3 проблеми підготовки до сімейного життя, відчувати яку вони починають вже у підлітковому віці.

3. Найбільш мало відомим компонентом для молоді є репродуктивне здоров'я, сексуальна культура, гігієна.

У зв'язку з цим постала гостра необхідність розробки психолого-педагогічної програми підготовки до сімейного життя. Через це наступним етапом вивчення проблеми готовності молоді до сімейного життя став формуючий експеримент. Дана програма складалася 3 двох блоків: формування загальних уявлень про сім'ю i формування уявлень про репродуктивні функції. Блок занять включав в себе наступні теми: 1. Поняття «сім'я», основні види шлюбних сценаріїв, типи психологічних відносин у шлюбі, дитячо-батьківські від- носини, сімейні конфлікти. Аналіз результатів апробації психолого-педагогічної програми підготовки до сімейного життя проводився за допомогою наступних методик на контрольному етапі експерименту: 1. методика «РОП», 2. анкети «Правда і міфи про сексуальність».

Ми проаналізували результати дослідження та побачили позитивні зміни: молоді люди адекватно ставляться до збереження свого репродуктивного здоров'я та культурі статевих взаємин, також реально представляють умови для благополуччя сім'ї та гідного виховання дітей, що на даному етапі, відповідно до віку випробовуваних, свідчить про достатнє досягнення готовності до сімейного життя. За сумою отриманих результатів юнаки більш відповідально підійшли до розгляду даної проблеми, їх більш зацікавив аспект статевого виховання, безпосередньо соціальної та репродуктивної функції, що дозволило їм більше розкритися. 3 психолого-педагогічної точки зору це пояснюється тим, що $з$ дівчатами в силу фізіології та гігієни в більшому обсязі проводяться бесіди та роз'яснення. Юнаки менш контактні як 3 матерями, так і з батьками. У зв'язку з цим, дефіцит необхідної інформації дозволив їм в ході занять зайняти більш відкриту позицію. Затребуваність інформації у молоді виявилась високою, що і позначилося на результатах.

Висновки та перспективи подальшого дослідження. Підготовка підростаючого покоління до сімейного життя $\epsilon$ невід'ємною частиною виховання. Усвідомлене батьківство є складною, динамічною структурою, яка включає батьківські установки, батьківську відповідальність, педагогічні знання і уміння батьків, стиль сімейного виховання. Зв'язок компонентів між собою здійснюється через пересічення їх складових елементів: когнітивного, емоційного і поведінкового аспектів, які є критеріями реалізації цих компонентів. Сумарним виразом всіх компонентів і найбільш доступним для зовнішнього спостереження, є стиль сімейного виховання. Від якості реалізації цього аспекту багато в чому залежить соціалізація підростаючого по- 
коління, якість і благополуччя майбутніх сімей. В цілому за результатами аналізу та спостережень ми побачили позитивні зміни у формуванні готовності молоді до сімейного життя після впровадження в одній із загальноосвітніх шкіл програми під-

\section{Список використаних джерел:}

1. Алешина Ю. Е. Цикл развития семьи: Исследования и проблемы / Ю. Е. Алешина // Вест. Моск. Ун-та. Психология. Сер.14. — 2011. — №2. — С. 60-72.

2. Варга А. Я. Семья в психологической консультации: опыт и проблемы психологического консультирования / А. Я. Варга. - М., 2012. - 208 с.

3. Головаха Е.И. Постсоветская аномия: особенности выхода из состояния аномическойдеморализованности в России и Украине / Е. И. Головаха, Н. В. Панина // Общественные науки и современность. - 2013. - № 6. - С. 5-10.

4. Исаев Д.Н. Половое воспитание и психогигиена пола у детей / Д.Н. Исаев, В.Е. Каган. — Л. : Медицина, 2014. - 184 с.

5. Каптерев П.Ф. О семейном воспитании : учеб. пособие для студентов / П.Ф. Каптерев ; сост. и авт. комент. И.Н. Андреева. — М., 2014. - 168 с.

6. Куликова Т.А. Семейная педагогика и домашнее воспитание : учеб. пособие для вузов / Т. А. Куликова. - М. : Академия, 2013. - С. 225.

7. Левкович В. П. Методика диагностики супружеских отношений / В. П. Левкович, О. Э. Зуськова // Вопросы психологии. - 2014. - № 4. - С. 128-134.

8. Шапиро Ю.Б. Половое воспитание, сексуальное образование и подготовка к семейной жизни / Ю.Б. Шапиро // Российская энциклопедия социальной работы. В 2-х т. / Под ред. А. М. Панова и Е.И. Холостовой. - М. : Институт социальной работы, 2013. - Т. 2. - С. 131-137.

Аннотация. В статье рассматриваются проблемы формирования у современной молодежи представления про создание собственной семьи и готовности к ответственному отцовству. Процессы становления молодых семей сейчас в большинстве случаев проходит в сложных и противоречивых условиях, которые характеризуются сменой социальных отношений и появлением новые иенностей. Рассмотрены пути решения этой проблемы, предложены мероприятия по их предупреждению путем особенных подготовок молодого поколения к созданию семьи.

Ключевые слова: личность, готовность молодежи к семейной жизни, ответственное отцовство, становление молодой семьи, супружество, общество, молодежь, семейная адаптация, проблемы семьи, иенности.

Abstracts. The article deals with the problem of forming modern youth perceptions of their own family and the willingness to responsible parenthood. Processes of formation of young families now in place in most embodiments, complex and contradictory conditions that are characterized by changes in social relations and the emergence of new values. Discussed ways to solve this problem, a method of preventing it, by preparing the younger generation to create a family.

Keywords: personality, willingness of young people to family life, responsible parenthood, the emergence of a young family, marriage, society, youth, family adaptation, family problems, values. 